\title{
Ophthalmology in images
}

\section{Oftalmología en imágenes}

\section{Andreas Di Luciano', Caroline Tsimi ${ }^{2}$ and Thomas Johnson ${ }^{3,4}$}

${ }^{1}$ Flying Eye Hospital, Orbis International, New York, United States; ${ }^{2}$ Hospital Central, Yaounde, Cameroon; ${ }^{3}$ University of Miami, Miami, United States; ${ }^{4}$ Bascom Palmer Eye Institute, Miami, United States

A 50-year-old patient, without relevant medical history, was attacked with a knife, receiving an injury in his left orbit (Fig. 1). The patient was transferred to the emergency room.

In the initial evaluation, the patient had a normal neurological examination and hemodynamic stability.

Ophthalmological examination showed that the sharp object was located in the medial region of the left orbit. The surrounding tissue had edema, hindering the evaluation of that eye. The right eye (OD) was normal.

An orbit computed tomography scan showed a radiopaque orbital foreign body located between the eyeball and the medial wall of the orbit, with a fracture involving the ethmoidal bone on the left orbit (Figs. 2 and 3).

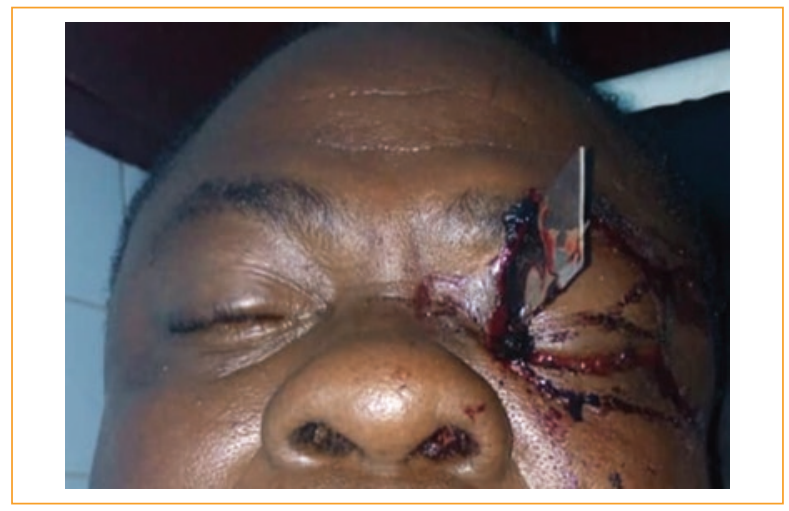

Figure 1. Front view of the patient. Ocular injury in the left orbit. Foreign body recognized as a knife.

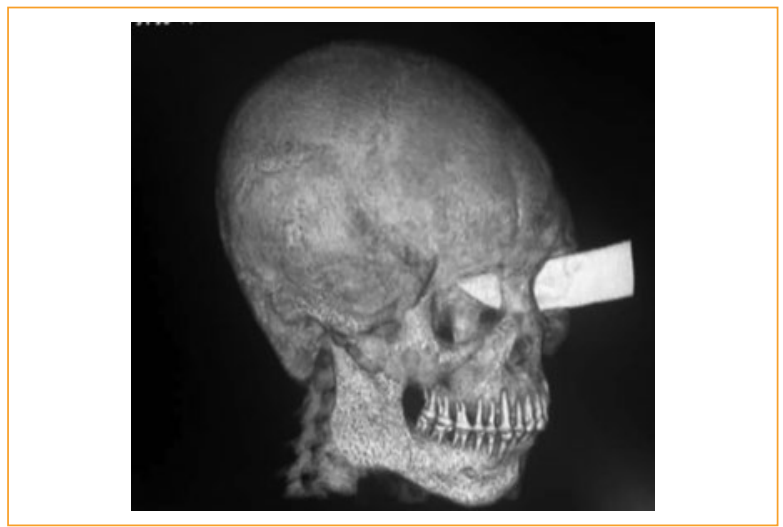

Figure 2. Orbit computed tomography scan. Orbital foreign body in the left orbit.

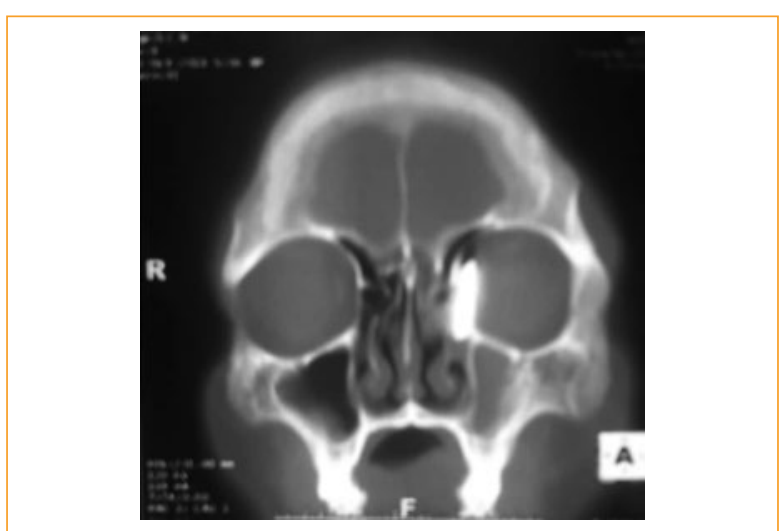

Figure 3. Orbit computed tomography scan, coronal cut. Intraorbital radiopaque foreign body is observed. It is located between ocular globe and the medial wall of the orbit.
Correspondence:

*Andreas Di Luciano
E-mail: andreasdilu@gmail.com

Available online: 02-01-2020 2604-1731/C 2020 Sociedad Mexicana de Oftalmología. Published by Permanyer. This is an open access article under the CC BY-NC-ND license (http:// creativecommons.org/licenses/by-nc-nd/4.0/). 
The foreign body was removed under general anesthesia, suturing and repairing tissues by layers. On examination, there was no evidence of foreign body penetration into the eyeball. The patient received analgesics and antibiotics after the procedure, with good evolution at $48 \mathrm{~h}$.

At this time point, BCVA was 20/40 in OD and 20/50 in OS. OS examination revealed a normal anterior segment, reactive pupils with normal pupillary light reflex as well as normal eye fundus. Visual fields showed no alterations. There was only a slight limitation of adduction with the ipsilateral eye.

\section{Ethical disclosures}

Protección de personas y animales. Los autores declaran que para esta investigación no se han realizado experimentos en seres humanos ni en animales.

Confidencialidad de los datos. Los autores declaran que han seguido los protocolos de su centro de trabajo sobre la publicación de datos de pacientes.

Derecho a la privacidad y consentimiento informado. Los autores han obtenido el consentimiento informado de los pacientes y/o sujetos referidos en el artículo. Este documento obra en poder del autor de correspondencia. 